\title{
Effectiveness and side effects of complementary and alternative therapies in acne
}

\section{Eficacitatea şi efectele adverse ale terapiilor complementare şi alternative în acnee}

\author{
Ana Maria Alexandra STĂNESCU ${ }^{1}$, loana Veronica GRĂJDEANU ${ }^{1}$, Constantin ŞTEFAN ${ }^{1}$, \\ Bogdan ŞERBAN ${ }^{1}$, Camelia Cristina DIACONU ${ }^{1,2}$ \\ ${ }^{1}$ Universitatea de Medicină şi Farmacie „Carol Davila“, Bucureşti, România \\ ${ }^{2}$ Spitalul Clinic de Urgenţă Bucureşti, România
}

\section{ABSTRACT}

Acne is a condition that occurs in both sexes, affects several age groups (especially adolescents) and can have a high degree of impairment of the quality of life of patients. Therapies prescribed by the physician are generally long-lasting and may have significant side effects. Patients tend to try other therapies, either concomitantly with those prescribed by the physician or by replacing them. This analysis seekstohighlightthemechanisms of action, efficacyandthe adverse effects of alternative and I or complementarytherapiesused in acne.
\end{abstract}

Keywords: acne, therapies, efficacy, side effects

\section{REZUMAT}

Acneea reprezintă o afecțiune care apare la ambele sexe, afectează mai multe grupe de vârstă (în special adolescenții) ş̧ poate avea un grad ridicat de afectare a calității vieții pacienților. Terapiile prescrise de către medic sunt în general de lungă durată şi pot avea efecte secundare semnificative. Pacienții tind să apeleze şi la alte terapii, fie concomitent cu cele prescrise de medic, fie înlocuindu-le. Această analiză doreşte evidențierea mecanismelor de acțiune, eficacitatea, dar şi efectele adverse ale unor terapii alternative şi/sau complementare folosite in acnee.

Cuvinte cheie: acnee, terapii, eficacitate, efecte adverse

\section{INTRODUCERE}

Acneea vulgară este o dermatoză inflamatorie cronică ce prezintă caracteristic comedoane deschise sau închise şi leziuni inflamatorii, incluzând papule, pustule sau noduli. Acneea este o afecţiune comună a pielii ce afectează în mod special adolescenţii şi adulţii tineri. Poate reprezenta cel mai frecvent diagnostic dermatologic pentru 22-32\% dintre cazuri şi este unul dintre cele mai frecvente motive pentru vizitarea unui medic $(1,1 \%)(1)$. Poate să apară la diverse grupe de vârstă, însă $85 \%$ dintre cazuri se întâlnesc la adolescenţi (2).

Din punct de vedere socio-economic, în anul 1995 în SUA au fost estimate 10,2 milioane de cazuri, reprezentând $25,4 \%$ dintre diagnosticele dermatologice ale tuturor medicilor; anual s-au 
eliberat 6,5 milioane de prescripţii pentru terapie sistemică (antibiotice sau izotretinoin), cu un cost de peste 1 miliard de dolari (3). Abordarea terapeutică diferă în funcţie de tipul de acnee: acneea vulgară, acneea fulminans, acneea conglobată, acneea medicamentoasă sau acneea la nou-născut şi sugar (4).

Acneea este o boală răspândită la nivel global, în special în rândul adolescenţilor. Terapia de bază este şi va rămâne cea prescrisă de medicul dermatolog. Cu toate acestea, pacienţii au tendinţa de a căuta metode alternative de tratament. Nu sunt multe studii care să fi urmărit eficacitatea acestor terapii, fie ele complementare sau alternative, în tratamentul acneei. Aceste terapii sunt utilizate la nivel mondial, însă sunt insuficient investigate în ceea ce priveşte siguranţa şi eficacitatea.

Terapiile complementare sunt împărţite în următoarele categorii: dietă şi nutriţie (macrobiotice, dieta Gerson, antioxidanţi); intervenţii mintale-corp (meditaţie, hipnoză, grupuri de sprijin); bioelectromagnetice (electromagnetice, electroacupunctură); remedii tradiţionale şi folclorice (naturopatia, Ayurveda, medicina chineză tradiţională, homeopatia); tratamente farmacologice şi biologice (antineoplaston, terapie de chelare, terapie de imuno-augmentare, cartilaj de rechin); metode de vindecare manuală (masaj, chiropractică, tactil terapeutic); medicina pe bază de plante (5).

Medicina tradiţională chineză (una dintre cele mai importante componente ale medicinei complementare şi alternative) este un sistem tradiţional de asistenţă medicală bazat pe credinţele şi practicile culturii chineze şi filosofia antică, include medicina pe bază de plante, acupunctură sau moxibustion, masaj, terapie cupping, exerciţii terapeutice, cum ar fi tai chi, şi terapie dietetică (6).

Scopul acestui articol este de a revizui literatura actuală cu privire la opţiunile terapeutice complementare şi alternative pentru acnee, urmărind eficacitatea acestora. S-au utilizat bazele de date PubMed şi Scopus pentru a găsi articole relevante pentru această temă.

\section{Dieta}

Impactul dietei asupra evoluţiei acneei este încă un subiect foarte controversat, dar nu poate fi trecut cu vederea. Dacă pacientul constată o asociere între un anumit factor alimentar şi severitatea acneei, el trebuie instruit să îl excludă din dietă sau să-şi limiteze consumul. Influenţa dietei asupra severităţii acneei necesită în continuare cercetări, dar nu ar trebui să mai fie o dogmă dermatologică pentru a afirma că orice asociere între dietă şi acnee este un mit.

Lapte și produsele lactate - cauza probabilă a posibilelor efecte comedogene ale laptelui şi produselor lactate este conţinutul de hormoni produs de vaci în timpul sarcinii (7). Se crede că factorul din lapte care stimulează în cea mai mare parte unitatea pilosebacee este factorul de creştere asemănător insulinei 1 (IGF-1), a cărui concentraţie în sânge variază în funcţie de gravitatea acneei (8). Nivelurile plasmatice ridicate ale IGF-1, care pot fi cauzate de consumul de lapte, stimulează proliferarea sebocitelor, ducând la dezvoltarea şi progresia leziunilor acneice (9). Atât IGF-1, cât şi androgenii stimulează producţia de sebum, care este unul dintre factorii patogeni ai formării acneei (10).

Adăugarea hormonilor exogeni derivaţi din dietă la grupul de hormoni endogeni poate avea un impact semnificativ. Laptele care este disponibil în magazine nu este numai bogat în progesteron derivat din placentă, dar şi în alţi precursori ai dihidrotestosteronului (DHT), cum ar $\mathrm{fi}$ $5 \alpha$-pregnanediona şi $5 \alpha$-androstanediona; aceşti compuşi sunt uşor modificaţi enzimatic la DHT şi enzimele necesare pentru acest proces sunt disponibile în unitatea pilosebace (11). Atât precursorii de testosteron, cât şi moleculele 5a-reduse sunt considerate a contribui la comedogenicitatea laptelui, acţionând prin stimularea producţiei de sebum şi prin inducerea hiperkeratinizării unităţii pilosebace (11). De asemenea, este posibil ca echilibrul hormonal al laptelui degresat să fie afectat, putând afecta comedogeneza.

Adebamowo şi colab., în urma studiului derulat în 2005, au asociat pozitiv acneea cu cantitatea de lapte ingerat, în special cu lapte degresat, dar şi cu produsele care conţin lapte (laptele degresat conţine mai puţin estrogen decât laptele integral, estrogenul fiind un hormon care poate reduce acneea) (12). În 2006 şi 2008, tot Adebamowo şi colab. au evidenţiat corelaţia pozitivă între consumul de lapte (indiferent de grăsime) şi acnee la fete şi, de asemenea, au găsit o corelaţie pozitivă între consumul de lapte degresat şi acneea la băieţi $(10,13)$.

Ciocolata - a fost considerată ca un factor care poate contribui la exacerbarea acneei, fiind posibilă observarea, la unii pacienţii, a unor leziuni acneice noi la câteva zile după ingerarea produselor care conţin ciocolată (11). Rezultatele studiilor în ceea ce priveşte consumul de ciocolată diferă semnificativ. În Grecia, $66 \%$ dintre 
participanţii la studiu au asociat consumul de ciocolată cu agravarea acneei (14). Fulton şi colab. nu au observat nicio diferenţă în compoziţia sebumului la consumatorii de ciocolată şi, prin urmare, nu a fost găsită nicio asociere între consumul de ciocolată şi agravarea leziunilor acneice (15). Studiile privind efectul ciocolatei asupra stării pielii sunt controversate şi inexacte din cauza ingredientelor suplimentare (lapte, zahăr etc.). Nu există informaţii suficiente privind tipul de ciocolată consumat de subiecţi şi procentul de cacao, care pot influenţa rezultatele; ciocolata neagră conţine mai mulţi antioxidanţi decât ciocolata cu lapte, ceea ce ar conduce la concluzia că aceasta poate avea efecte comedogenice mult mai mici (16).

Indexul glicemic - dieta bazată pe produse cu indice glicemic ridicat conduce la hiperinsulinemie, nivelurile ridicate de insulină stimulează secreţia de androgeni şi produc o creştere a producţiei de sebum, care joacă un rol fundamental în patogeneza acneei vulgare $(11,17)$. Hiperinsulinemia afectează nivelul IGF-1 şi proteina de legare a factorului de creştere a insulinei (IGFBP-3), care afectează în mod direct proliferarea şi apoptoza keratinocitelor. În ceea ce priveşte dieta, populaţiile occidentale au o frecvenţă mai mare a acneei; studii efectuate în populaţii din Papua-Noua Guinee şi Paraguay au constatat lipsa acneei, cel mai probabil datorită dietei cu indice glicemic scăzut şi fără alimente rafinate occidentale $(18,19)$. Cordain şi colab. au demonstrat că hiperinsulinemia indusă de dietă duce la o cascadă a răspunsurilor sistemului endocrin care pot afecta dezvoltarea acneei prin acţiunea androgenilor, căilor de semnalizare IGF-1, IGFBP-3 şi retinoidului; hiperinsulinemia poate fi un factor de risc în dezvoltarea acneei, prin afectarea proliferării epidermei în foliculul de păr, hiperkeratinizarea şi secreţia de sebum controlată de androgen (20). Mai multe studii efectuate pe populaţii din mediul rural (cu o dietă tradiţională) au arătat lipsa leziunilor acneice, dar, o dată cu introducerea alimentaţiei occidentale la aceste populaţii, au început să apară leziunile acneice $(21,22)$.

Fibre - nu există studii clinice care să arate în mod clar efectul consumului de fibre dietetice în cursul acneei; cu toate acestea, Kaufman a demonstrat în studiul său că aportul zilnic a $30 \mathrm{~g}$ de cereale la micul dejun (13 g fibră / mic dejun) îmbunătăţeşte semnificativ starea pielii (23).

Acizi grași - raportul dintre acizii graşi omega-6 şi omega-3 care rezultă din dietă este unul dintre factorii care modulează mecanismul in- flamator, un aport ridicat de acizi graşi omega-3 poate inhiba producţia de citokine proinflamatorii, care pot avea un efect terapeutic asupra acneei (10). Fiecare unitate pilosebacee are capacitatea de a produce substanţe pro-inflamatorii, inclusiv leucotriena B4 (substanţă care reglează producţia de sebum), folosind substanţe care provin din descompunerea grăsimilor provenite din dietă (24). Cu toate acestea, acest subiect nu este foarte bine documentat, presupunându-se că această dietă poate fi benefică în tratamentul acneei. Hitch şi Greenburg, în 1961, au arătat că persoanele care consumă cantităţi mari de peşte şi fructe de mare au mai puţine simptome de acnee (puncte negre, papule, pustule, piele grasă) (25).

Antioxidanții - tipurile de oxigen reactiv produse de neutrofile participă la progresia inflamatorie a acneei. Speciile de oxigen reactiv sunt în mod normal îndepărtate prin antioxidanţi celulari, cum ar fi glucoză-6-fosfat dehidrogenază şi catalază, ambele fiind prezente în cantităţi mici la pacienţii cu acnee. S-a sugerat că stresul oxidativ poate fi implicat în originea acneei şi că medicamentele cu efecte antioxidante (sau suplimente antioxidante) pot fi adjuvanţi valoroşi în tratamentul acneei (10). S-a demonstrat că pacienţii cu acnee aveau concentraţii plasmatice semnificativ mai scăzute ale antioxidanţilor în comparaţie cu populaţia generală (26). Se poate susţine teoria rolului pozitiv al antioxidanţilor în tratamentul acneei, dar efectele acestor substanţe în cursul acneei nu sunt încă pe deplin elucidate.

Zinc, vitamina A și iod. Zincul este un micronutrient esenţial pentru dezvoltarea şi funcţionarea pielii umane. S-a demonstrat că este bacteriostatic împotriva Propionibacterium acnes, inhibarea chemotaxiei şi reducerea producerii de factori proinflamatori citokini - factor de necroză tumorală alfa (TNF- $\alpha$ ) (27). Vitamina A este reprezentată de un grup de compuşi care se găsesc atât în produsele animale, cât şi în cele vegetale. Retinolul şi derivaţii săi se găsesc în principal în produsele de origine animală, în timp ce produsele de origine vegetală conţin în principal provitamina A (carotenoide). Kligman şi colab. au arătat că suplimentarea orală cu vitamina A (retinol) este eficientă în tratamentul acneei atunci când este utilizată în doze mari (300.000 U/zi pentru femei şi 400.000-500.000 U/zi pentru bărbaţi) (28). Acneea care apare după ingerarea alimentelor bogate în iod apare brusc şi se caracterizează prin multe papule (10). 


\section{Acupunctura}

Acupunctura este un sistem de terapie medicală care este folosit în China de mai mult de 2.500 de ani în tratamentul tuturor bolilor umane şi veterinare (29). În chineză, practica este numită Zhen Jiu, denumirea „acupunctură“ este derivată din latină şi înseamnă „puncţia pielii“. Acele fine sterile sunt inserate în puncte şi zonele localizate ale pielii şi ale ţesutului subcutanat şi muscular pentru a iniţia răspunsuri fiziologice de reparare şi reglare în organism (30).

Acupunctura este frecvent utilizată în practică pentru afecţiunile cutanate, totuşi există un decalaj în evaluarea eficacităţii şi siguranţei acupuncturii pentru acnee. S-a arătat că şansa de îmbunătăţire a simptomelor acneei este de $\geq 30 \%$ şi $\geq 50 \%$ în cazul acupuncturii corporale, electroacupuncturii şi acupresurii auriculare, fără diferenţe statistice în ceea ce priveşte comparaţia cu tratamentul medicamentos pentru acnee (31).

Rata terapeutică efectivă este o măsurătoare comună în studiile medicinei chineze, pentru acnee se urmăreşte schimbarea numărului de leziuni sau severitatea. Sunt unele studii care au arătat că acupunctura ar avea aceeaşi eficacitate cu antibioticele, în timp ce alte studii au arătat aceeaşi eficacitate cu retinoizii topici şi orali $(32,33)$. Retinoizii şi antibioticele, deşi sunt eficace, au inconveniente; se poate crea rezistenţă la antibiotice atunci când sunt utilizate pe termen lung, iar retinoizii trebuie utilizaţi cu precauţie din cauza efectelor adverse (34).

Acupunctura şi acupresura auriculară au mai puţine efecte secundare şi pot fi o opţiune pentru cei care doresc un tratament alternativ la produsele farmaceutice. Durata tipică a tratamentului pentru acupunctura corporală este de 20 până la 30 de minute pentru fiecare tratament, iar frecvenţa tratamentului poate varia de la 1 la 5 ori pe săptămână, în funcţie de mediul de practică locală (35).

\section{Plantele medicinale}

Plantele medicinale s-au dovedit a avea efecte secundare reduse, posedă capacitatea de a diminua efectele adverse induse de medicamente şi chiar de metale grele sau de alte toxicităţi $(36,37)$. Medicamentele pe bază de plante câştigă o popularitate crescută datorită avantajelor lor, cum ar fi toleranţa mai bună a pacientului, istoricul lung de utilizare, mai puţine efecte secundare şi relativ mai puţin costisitoare
(36). Multe plante medicinale cu acţiune antiinflamatoare şi antibacteriană sunt utilizate în moduri diferite în tratamentul acneei şi al altor boli infecţioase.

Matricaria recutita, Calendula officinalis şi Triticuma estivum sunt specii uzuale ale acestor plante sub formă de creme sau infuzări apoase din plante, inclusiv astringentele şi compozitele, cum ar fi taninurile, sunt utilizate local pe piele după curăţare sau după o baie de aburi (38). Alte plante care conţin tanini sunt coaja de stejar alb (Quercus alba), frunza de nucă (Juglans regia), Agrimonia eupatoria, Syzygiumcuminum, Syzygiumcuminum, Ledumlatifolium, Alchemillamollis, Lavandulaangustifolia, Verbascumthapsus, Krameriatriandra, Rheumpalmatum, Hypericumperforatum și Rumexcrispus (39).

Vitexagnus castus este utilizat pentru acnee înainte de menstruaţie, fiind recomandată administrarea zilnică a $40 \mathrm{mg}$ de extract. Nu se administrează la gravide şi la femeile care alăptează (au fost raportate reacţii adverse: tulburări gastro-intestinale şi erupţii cutanate) (40).

În ceea ce priveşte activitatea antibacteriană, s-a arătat că acidul usnic are un efect inhibitor puternic asupra creşterii $P$. acnes. Creşterea bacteriilor a fost inhibată la concentraţii $\geq 1 \mu \mathrm{g}$ / $\mathrm{ml}$ şi s-a descoperit că are o gamă largă de proprietăţi antioxidante şi antibacteriene, sugerând că aceasta poate fi o substanţă promiţătoare în tratamentul acneei (41).

Un studiu a arătat că aplicarea topică a esenței $O$. gratissimum a fost superioară faţă de placebo şi clindamicină $1 \%$. În acest studiu, aloe vera de culoare galbenă locală nu a fost numai eficientă în tratamentul acneei, însă a arătat o interacţiune sinergică cu $O$. gratissimum (42). Utilizarea topică a gelului de $50 \%$ aloe vera cu cremă de tretinoin a fost bine tolerată timp de opt săptămâni într-un studiu clinic randomizat dublu-orb pe 60 de pacienţi care sufereau de acnee uşoară şi moderată (43).

Utilizarea a $2 \%$ loţiune de ceai verde ( $\mathrm{Ca}$ mellia sinensis) local, în decurs de şase săptămâni, la 20 de pacienţi care sufereau de acnee uşoară până la moderată, s-a dovedit a fi eficientă în comparaţie cu tratamentul prealabil (44). Principalele substanţe active ale extractelor Mahonia includ doi alcaloizi de protoberberine, şi anume jatrorhizină şi berberină, care au inhibat creşterea in vitro a speciilor de Staphylococcus coagulase, P. acnee şi Candida (45). 
TABELUL 1. Plante utilizate în tratamentul acneei

\begin{tabular}{|c|c|}
\hline Denumire & Mențiuni \\
\hline Achyranthesaspera & $\begin{array}{l}\text { Plantă medicinală folosită în mod tradiţional pentru tratamentul acneei vulgaris, erupţii ale } \\
\text { pielii, scabie şi alte boli ale pielii. }\end{array}$ \\
\hline Alliumcepa & $\begin{array}{l}\text { Ceaiul din extractul de ceapă are capacitatea de a îmbunătăţi aspectul cicatricilor la pacienţii cu } \\
\text { cheratoză seboreică. Are proprietăţi an obiene şi an a Malassezia furfur, } \\
\text { Candida albicans şi a altor Candida sp., precum şi a unor tulpini de dermat } \\
\text { din acneea vulgară. }\end{array}$ \\
\hline Azadirachta indica & $\begin{array}{l}\text { S-a arătat că o formulă an } \quad \text { ă preparată din extracte din plante, conţinând extractul de } \\
\text { etanol din Azadirachta indica, G. glabra, Andrographis paniculata, Ocimumsanctum şi ceai } \\
\text { verde, posedă potenţialul de inhibare a acneei, acţionat cu succes împotriva Propionibacterium } \\
\text { şi Staphylococcus epidermis. }\end{array}$ \\
\hline Cannabissativus & $\begin{array}{l}\text { Uleiul de seminţe de Cannabissativus est } \\
\text { seboreică, eczemă, derma ă,?̧psoriazis şi lichen planus. }\end{array}$ \\
\hline
\end{tabular}

\section{CONCLUZII}

În general, aceste terapii nu sunt prescrise de către medicul specialist. Ele sunt utilizate pe scară largă de către pacienţi, cu atât mai mult cu cât nu au nevoie de prescripţie şi tind să fie mai puţin costisitoare. Unele dintre aceste terapii tind să aibă eficacitate, însă nu se poate şti cu siguranţă dacă pot înlocui terapia clasică. Necesitatea studiilor pe scară largă pe această temă este evidenţiată, fiind necesar un ghid al terapiilor alternative pentru acnee. Ghidul trebuie să cuprindă clar modalitatea corectă de abordare a dietei, dar şi dozele şi modalitatea de administrare a plantelor medicinale, pentru ca acestea să aibă efect în tratamentul acneei.

Conflict of interest: none declared Financial support: none declared

\section{BIBLIOGRAFIE}

1. Zouboulis CC. Acne and sebaceous gland function. Clin Dermatol. 2004;22:360-366

2. Bhate $\mathrm{K}$, Williams $\mathrm{HC}$. Epidemiology of acne vulgaris. Br J Dermatol. 2013;168(3):474-485.

3. Zouboulis CC, Eady A, Philpott M et al. What is the pathogenesis of acne? Exp Dermatol. 2005;14:143-152

4. Stănescu AMA, Matei A, Grăjdeanu IV, Goanta AM, Giurcaneanu C. Acneea fulminans - urgenţă medicală în practica medicului de familie. Practica Medicală 2017;12,4(53):224-227.

5. A report to the National Institutes of Health on alternative medical systems and practices in the United States. Washington DC: US GovernmentPrinting Office; 1992. Alternative medicine: expanding medical horizons. [Workshop on Alternative Medicine]

6. Cao H, Yang G, Wang Y et al. Complementary therapies for acne vulgaris. Cochrane Database Syst Rev. 2015;1:CD009436. Published 2015 Jan 19. doi:10.1002/14651858.CD009436.pub2

7. Kucharska A, Szmurło A, Sińska B. Significance of diet in treated and untreated acne vulgaris. Postepy Dermatol Alergol. 2016;33(2):81-86. doi:10.5114/ ada.2016.59146

8. Danby FW. Acne and milk, the diet myth, and beyond. J Am Acad Dermatol. 2005;52:360-2.
9. Melnik BC. Milk - the promoter of chronic Western diseases. Med Hypoth. 2009;72:631-9.

10. Bowe WP, Joshi SS, Shalita AR. Diet and acne. J Am Acad Dermatol. 2010;63:12441.

11. Adilson $C$, Thais Abdalla M. Acne and diet: Truth or myth? An Bras Dermatol. 2010;85:346-53.

12. Adebamawo CA, Spiegelman D, Danby FW et al. High school dietary dairy intake and teenage acne. J Am Acad Dermatol. 2005;52:207-14

13. Adebamowo CA, Spiegelman D, Berkey CS et al. Milk consumption and acne in teenaged boys. J Am Acad Dermatol. 2008;58:787-93.

14. Spencer EH, Ferdowsian HR, Barnard ND. Diet and acne: a review of evidence. Int $J$ Dermatol. 2009;48:339-47.

15. Fulton, J.E. Jr., Plewig, G., Kligman, A.M. Effect of chocolate on acne vulgaris. J Am Acad Dermatol. 1969;210:2071-2074

16. Block SG, Valins WE, Caperton CV et al. Exacerbation of facial acne vulgaris after consuming pure chocolate. J Am Acad Dermatol. 2011;65:e114-5.

17. Emiroğlu N, Cengiz FP, Kemeriz F. Insulin resistance in severe acne vulgaris. Postep Derm Alergol. 2015;32:281-5.

18. Wolf $\mathrm{R}$, Matz $\mathrm{H}$, Orion $\mathrm{E}$. Acne and diet. Clin Dermatol. 2004;22:387-93.
19. Cordain L, Lindeberg S, Hurtado M et al. Acne vulgaris: a disease of Western civilization. Arch Dermatol. 2002;138:158490.

20. Cordain L, Eades MR, Eades MD. Hyperinsulinemic diseases of civilization: more than just syndrome X. Comp Biochem Physiol. 2003;136:95-112.

21. Schaefer $O$. When the Eskimo comes to town. Nutr Today. 1971;6:8-16.

22. Bendiner E. Disastrous trade-off: Eskimo health for white "civilization" Hosp Pract. 1974;9:156-89.

23. Kaufman WH. The diet and acne. Arch Dermatol. 1983;119:276.

24. Calder PC. Omega-3 fatty acids and inflammatory processes. Nutrients. 2010;2:355-74.

25. Hitch JM, Greenburg BG. Adolescent acne and dietary iodine. Arch Dermatol. 1961;84:898-911.

26. El-Akawi Z, Abdel-Latif N, Abdul-Razzak K. Does the plasma level of vitamins $A$ and $E$ affect acne condition? Clin Exp Dermatol. 2006;31:430-4.

27. Bowe WP, Shalita AR. Effective over-thecounter acne treatments. Semin Cutan Med Surg. 2008;27:170-6.

28. Kligman AM, Mills OH, Jr, Leyden JJ et al. Oral vitamin $A$ in acne vulgaris: preliminary report. Int J Dermatol. 1981;20:278-85. 
29. Kaptchuk TJ. Acupuncture: Theory, efficacy, and practice. Ann Intern Med. 2002;136(5):374-383

30. Langevin HM. Acupuncture, connective tissue, and peripheral sensory modulation. Crit Rev Eukaryot Gene Expr. 2014;24(3):249-253

31. Mansu SSY, Liang $H$, Parker S et al. Acupuncture for Acne Vulgaris: A Systematic Review and Meta-Analysis. Evid Based Complement Alternat Med. 2018;2018:4806734.

32. Zheng X. Y. Guideline for New Chinese Herbal Medicine in Clinical Practice and Research. Chinese Medical Science and Technology Publishing House; 2002.

33. State Administration of TCM. Guideline for New Chinese Herbal Medicine in Clinical Practice and Research. Guideline for New Chinese Herbal Medicine; 1994.

34. Eichenfield LF, Krakowski AC, Piggott $C$ et al. Evidence-based recommendations for the diagnosis and treatment of pediatric acne. Pediatrics. 2013;131(3):S163-S186.

35. Hao X, Xue C C, Dong L, Zheng Z. Factors associated with conflicting findings on acupuncture for tension-type headache:
Qualitative and quantitative analyses. The Journal of Alternative and Complementary Medicine. 2013;19(4):285-297.

36. Rafieian-Kopaei M. Medicinal plants and the human needs. J Herb Med Pharmacol. 2013;1(1):1-2.

37. Shirzad H, Taji F, Rafieian-Kopaei M. Correlation between antioxidant activity of garlic extracts and WEHI-164 fibrosarcoma tumor growth in BALB/c mice. J Med Food. 2011;14(9):969-74.

38. Kraft K. Erkrankungen der Haut (2) Weitere Ekzemformen, Akne und Pruritus. Zeitschrift für Phytotherapie. 2007; 28(3):129-33.

39. Peirce A. The American Pharmaceutical Association practical guide to natural medicines. New York: Morrow; 1999.

40. Wuttke W, Jarry H, Christoffel V, Spengler B, Seidlova-Wuttke D. Chastetree (Vitexagnus castus) - pharmacology and clinical indications. Phytomedicine. 2003; 10(4):348-57.

41. Weckesser S, Engel K, Simon-Haarhaus B, Wittmer A, Pelz K, Schempp CM. Screening of plant extracts for antimicrobial activity against bacteria and yeasts with dermatological relevance. Phytomedicine. 2007;14(7-8):508-16.

42. Orafidiya LO, Agbani EO, Oyedele AO, Babalola OO, Onayemi O, Aiyedun FF. The effect of aloe vera gel on the antiacneproperties of the essential oil of Ocimum gratissimum Linn leaf - a preliminary clinical investigation. Int $\mathrm{J}$ Aromather. 2004;14(1):15-21.

43. Balambal R, Thiruvengadam KV, Kameswarant L, Janaki VR, Thambiah AS. Ocimum basilicum in acne vulgaris - a controlled comparison with a standard regime. J Assoc Physicians India. 1985;33(8):507-8.

44. Blumenthal M, Busse WR, Godlberg A, editors. The Complete German Commission E Monographs; Therapeutic Guide to Herbal Medicines; 1998; Austin, Texas. American Botanical Council.

45. Slobodnikova L, Kost'alova D, Labudova D, Kotulova D, Kettmann V. Antimicrobial activity of Mahonia aquifolium crude extract and its major isolated alkaloids. Phytother Res. 2004;18(8):674-6. 